Open Access to Pharmaceutical and Medical Research

(C) 2011-18, publisher and licensee JDDT, This is an Open Access article which permits unrestricted non-commercial use, provided the original work is properly cited

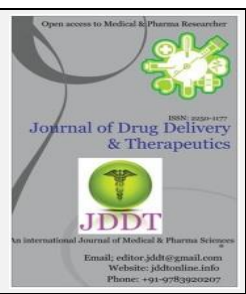

Open $\odot$ Access

Research Article

\title{
Ameliorative effect of Ipomoea pes-caprae ethanolic leaf extract on carbohydrate metabolizing enzymes and oxidative status in Streptozotocin- induced diabetic Wistar rats
}

\author{
S. Suhasini $\mathrm{a}^{*}$, C. Elanchezhiyan ${ }^{\mathrm{b}}$ and G. Chandirasegaran c \\ a Department of Zoology, Thiruvalluvar University Model Constituent College of Arts and Science, Tittagudi 606 106, Tamil Nadu, India \\ b Department of Zoology, Annamalai University, Chidambaram, Annamalai nagar 608 002, Tamil Nadu, India. \\ c Department of Microbiology, AVS College of Arts and Science, Ramalingapuram 636 106, Salem, Tamil Nadu, India
}

\begin{abstract}
In diabetic patients, hyperglycemia is developed due to increased hepatic glucose production and impaired utilization of gluc ose in cells, which leads to oxidative stress in cells. Ipomoea pes-caprae has been widely used as an oral treatment for many diseases. The aim of the present study is to assess the effect of Ipomoea pes-caprae ethanolic leaf extract on carbohydrate metabolizing enzymes and oxidative status in Streptozotocin (STZ) induced experimental diabetic rats. Experimental diabetic rats were induced by intraperitoneal administration of $55 \mathrm{mg} / \mathrm{kg}$ b.w of STZ. Diabetic rats were treated with I. pes-caprae ethanolic leaf extract at a concentration of $300 \mathrm{mg} / \mathrm{kg}$ b.w and glibenclamide (6 mg/kg b.w) for 45 days. Diabetic rats exhibited significant $(\mathrm{P}<0.05)$ decline in the activity of glucokinase and glucose-6-phosphate dehydrogenase, enzymatic antioxidants (SOD, CAT and GPx) and non-enzymatic antioxidants (GSH, vitamin E and vitamin C), while lipid peroxidation markers (LOOH and TBARS) and glucose-6-phosphatase and fructose-1, 6-bisphosphatase were found to be significantly increased. Further in diabetic rats, the histopathology of pancreas, liver and kidney showed abnormal histo-architecture. The treatment with Ipomoea pes-caprae ethanolic leaf extract notably reversed the abnormal levels in carbohydrate metabolizing enzymes, restored the oxidative status and abnormal structures in pancreas, liver and kidney to near normal levels.
\end{abstract}

Keywords: Diabetes, antioxidant, lipid peroxidation, Ipomoea pes-caprae and carbohydrate metabolizing enzymes.

Article Info: Received 07 July 2019; Review Completed 17 August 2019; Accepted 23 August 2019; Available online 30 Aug 2019

Cite this article as:

Suhasini S, Elanchezhiyan C, Chandirasegaran G, Ameliorative effect of Ipomoea pes-caprae ethanolic leaf extract on carbohydrate metabolizing enzymes and oxidative status in Streptozotocin-induced diabetic Wistar rats, Journal of Drug Delivery and Therapeutics. 2019; 9(4-A):167-175 http://dx.doi.org/10.22270/jddt.v9i4-A.3448

*Address for Correspondence:

S. Suhasini, Department of Zoology, Thiruvalluvar University Model Constituent College of Arts and Science, Tittagudi 606106 , Tamil Nadu.

\section{INTRODUCTION}

Diabetes mellitus (DM), a metabolic disorder, is characterized by disruption in the endocrine system due to multiple etiological factors, including chronic hyperglycemia and altered carbohydrate, fats, and proteins metabolism, which is caused by the defects in insulin secretion and/or action [1]. The prevalence of DM is expected to further increase to $9.9 \%$ (95\% CI $7.5-12.7 \%$ ) by the year 2045. In total, this reflects a population of 424.9 million people with diabetes worldwide in 2017 with an estimate of a $48 \%$ increase to 628.6 million people $(95 \%$ CI $477.0-808.7$ million) for the year 2045 [2].

The chronic hyperglycemia may lead to long-term oxidative cellular injury and dysfunction of various organs, particularly the kidneys, eyes, nerves, liver, heart, and blood vessels. The provoked oxidative stress and lipid peroxidation act as a potential pathophysiological mechanism underlying diabetic complications through the overproduction of reactive oxygen species and by triggering the production of proinflammatory cytokines, which together with reactive oxygen species are deemed to play vital roles in the pathogenesis of DM [3].

Nowadays, the utilization of herbal derived drugs has increased because of their superior activity, lesser side effects, as well as relatively low production cost. Thus, screening of novel antidiabetic alternative drugs from natural plant sources is of profound importance for the world [4].

I. pes-caprae is a common pan-tropical creeping vine belonging to the family Convolvulaceae. This plant is used as a medicinal plant in many countries for the treatment of several ailments, including anti-inflammatory and analgesic 
treatments [5]. All parts of I. pes-caprae are medicinally useful and are used in folk and traditional medicines for treating different diseases like stomach pain, fever and rheumatoid arthritis, etc., [6]. Earlier, some researchers reported that I. pes-caprae shows many biological activities such as anti-inflammatory activity Venkataraman et al. [7] anticancer activity Robert and Retna [8], antibacterial and antifungal activities (Bragadeeswaranet et al. [9] etc. Earlier, we reported that ethanolic leaf extract of $I$. pes-caprae regulated the abnormal blood glucose level and hepatic markers in STZ induced diabetic rats (Suhasini et al. [10] The objective of this present study is to observe the effect of ethanolic leaf extract of $I$. pes-capraeon on carbohydrate metabolizing enzymes, oxidative status and major organs (pancreas, liver and kidney) in STZ induced diabetic rats.

\section{MATERIALS AND METHODS}

\subsection{Experimental animals}

Male Wistar rats weighing 150-200 gms were used for the present study. The animals were obtained from the central animal house, Rajah Muthiah Institute of Health Sciences, Annamalai University, India and were maintained at $12 \mathrm{~h}$ light: dark cycles. All the animals were randomly divided into experimental and control groups. Animals were housed as 5 or 6 in each polypropylene cage. Standard pellets were obtained from Mysore snack feed Ltd., Mysore, was used as a basal diet during the entire experimental period. The control and the experimental animals were provided with food and drinking water ad libitum.

\subsection{Chemicals}

STZ was purchased from Sigma- Aldrich Pvt. Ltd., Bangalore, India. All the other chemicals as well as reagents used in this experiment were of analytical grade.

\subsection{Preparation of ethanolic leaf extract of Ipomoea pes- caprae}

I. pes-caprae was collected from Parangipettai, Tamil Nadu, India, and was identified by the Department of Botany, Annamalai University. The Ipomoea pes-caprae (Convolvulaceae) leaves were then separated and dried at room temperature, under the shade, and was powdered using a dry grinder and then passed through a sieve. Dried leaf powder (100 grams) of I. pes-caprae was packed in a soxhlet apparatus and was extracted with ethanol. The ethanol extract obtained was concentrated using a rotary evaporator.

\subsection{Induction of diabetes}

Diabetes was induced in male albino Wistar rats by a single intraperitoneal (I.P.) injection of streptozotocin (STZ) at a dose of $(55 \mathrm{mg} / \mathrm{kg} \mathrm{b.w})$ dissolved in $0.1 \mathrm{M}$ cold citrate buffer $(\mathrm{pH}=4.5)$. The rats were then allowed to drink $5 \%$ glucose solution overnight to overcome the drug-induced hypoglycemia. When the fasting blood glucose values reached above $250 \mathrm{mg} / \mathrm{dl}$, on the third day after STZ injection, then the rats were considered as diabetic.

\subsection{Experimental design}

The animals were maintained in accordance with the "CPCSEA guidelines for laboratory animal facility" (CPCSEA: Committee for the purpose of control and supervision of experiments on animals) and the approval number is (Pro.No.1030; Reg No.160/1999/CPCSE). The treatment of ethanolic leaf extract of I. pes-caprae at concentration of 300 $\mathrm{mg} / \mathrm{kg}$ b.w (dissolved in $0.05 \%$ dimethxyl sulfoxide (DMSO)) and glibenclamide (reference drug) at concentration of 6 $\mathrm{mg} / \mathrm{kg} \mathrm{b.w}$ was started on the fifth day after STZ injection and it was considered as the first day of treatment. Treatment was given for 45 days orally whereas control rats were administered with drug vehicle, i.e., $0.05 \%$ DMSO, and diabetic rats were fed with water alone.

A total number of 24 rats were used and the rats were divided into 4 groups of 6 animals in each group.

Group 1 : Control rats (drug vehicle: 0.05\% DMSO)

Group 2 : Diabetic control rats administered intraperitoneally with streptozotocin (as single dose: 55 $\mathrm{mg} / \mathrm{kg} \mathrm{b.w).}$

Group 3 : Diabetic rats administered with ethanolic extract of Ipomoea pes-caprae leaf $(300 \mathrm{mg} / \mathrm{kg}$ of body weight) for a period of 45 days.

Group 4 : Diabetic rats administered with reference drug glibenclamide $(6 \mathrm{mg} / \mathrm{kg}$ of body weight) for a period of 45 days.

On the 45th day, all the animals were sacrificed by cervical dislocation, and the blood samples were collected for analysis of biochemical parameters. The pancreas, liver and kidney were excised and washed with ice-cold saline to observe levels of carbohydrate metabolizing enzymes, antioxidant status and histopathological analysis.

\subsection{Determination of carbohydrate metabolizing enzymes}

Liver glycogen was evaluated by the method of Shirwaikar et al. [11]. The activity of hepatic glucokinase by the method of Brandstrup et al. [12], glucose-6-phosphate dehydrogenase by the method of Ellis and Kirkman [13], glucose-6phosphatase by the method of Koide and Oda [14] and fructose-1, 6-bisphosphatase activity were estimated by the method of Gancedo and Gancedo [15].

\subsection{Estimation of lipid peroxidation and antioxidants}

The activity of the thiobarbituric acid reactive substance (TBARS) and lipid peroxide (LOOH) in the liver was measured by the method of Ohkawa [16]. The activity of superoxide dismutase (SOD) was evaluated by the method of Kakkar [17]. The activity of catalase (CAT) enzyme was measured by the method given by Sinha, [18]. Glutathione Peroxidase (GPx) was evaluated by the method of Rotruck [19]. The activity of reduced glutathione (GSH) was assessed by the method of Ellman, [20]. Vitamin C and E levels were evaluated by the method of Omaye et al. [21] and Baker and Frank [22], respectively.

\subsection{Histopathology}

The harvested organs (pancreas, liver and kidney) were fixed in $10 \%$ formalin for $48 \mathrm{hrs}$. It was then followed by dehydration by passing through a series of graded alcohol and were finally embedded in paraffin blocks. Sections of pancreas, liver and kidney (5-6 $\mu \mathrm{m}$ thick) were developed using semi-automated rotator microtome. Finally, the sections obtained were stained with Hematoxylin and Eosin (H \& E) dye on a glass slide and observed microscopically.

\subsection{Statistical analysis}

All biochemical data were expressed as mean \pm SEM. All the statistical analysis was performed using the One-way ANOVA followed by Tukey's multiple tests using SPSS (version 18) of computer software. In all the cases, a $p$ value of less than 0.05 was considered to be statistically significant. 


\section{RESULTS}

\subsection{Effect of Ipomoea pes-caprae on liver glycogen}

Figure 1 shows the level of liver glycogen in normal and experimental rats. The level of liver glycogen was significantly reduced in diabetic control rats when compared to control rats. Treatment with $I$. pes-caprae leaf ethanolic extract and glibenclamide significantly improved the glycogen levels in the liver of diabetic rats when compared to diabetic control rats.

Figure 1: The liver glycogen levels in experimental and control rats

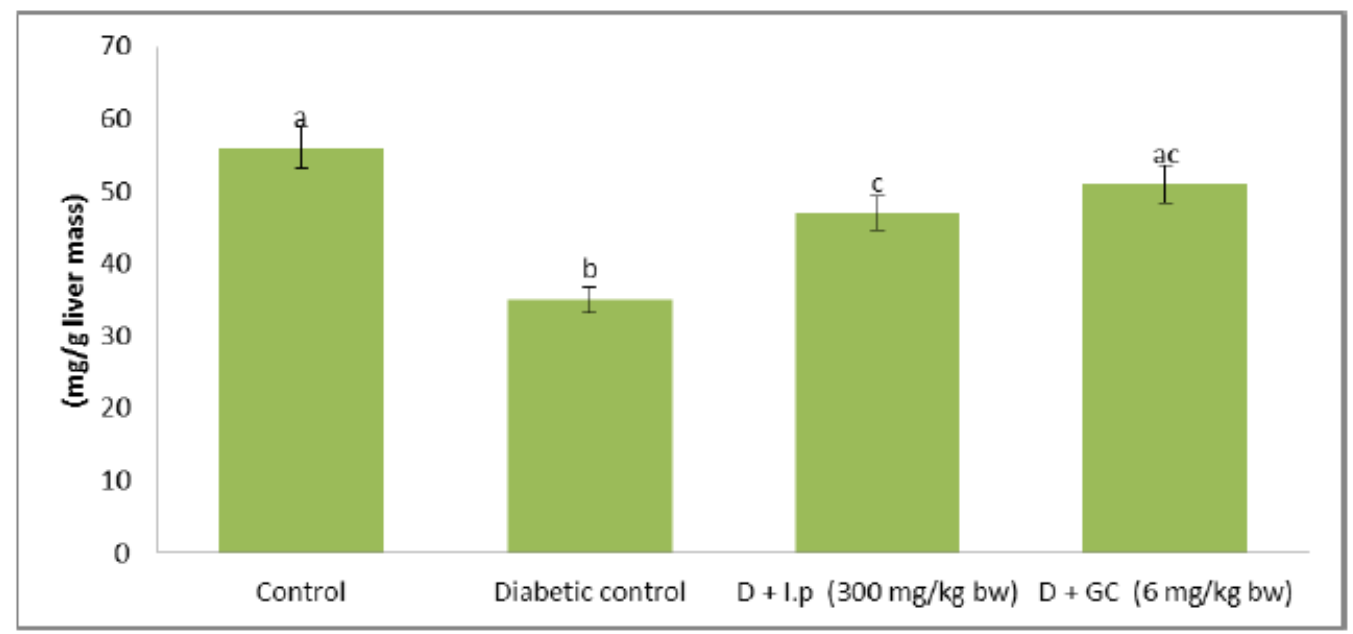

All the data were expressed as the mean \pm S.D. for 6 rats. The results with different superscripts

$(\mathrm{a}, \mathrm{b}, \mathrm{c}$. . $)$ in each experimental groups are significantly different at $\mathrm{p}<0.05$.

(D: Diabetic; I.p: I. pes-caprae leaf ethanolic extract; GC: Glibenclamide)

\subsection{Effect of Ipomoea pes-caprae on carbohydrate} metabolizing enzymes

Table 1 shows the level of carbohydrate metabolizing enzymes in experimental and control rats. The activity of hepatic glucokinase and glucose-6-phosphate dehydrogenase significantly declined, whereas glucose-6phosphatase and fructose-1, 6-bisphosphatase activity significantly elevated in the diabetic control rats. The abnormal levels of carbohydrate metabolizing enzymes were improved by $I$. pes-caprae leaf ethanol extract and glibenclamide treatment.

Table 1: The liver carbohydrate metabolizing enzyme levels in experimental and control rats

\begin{tabular}{|l|l|l|l|l|}
\hline Groups & $\begin{array}{l}\text { Hexokinase } \\
\left(\mathrm{U}^{*} / \mathrm{h} / \mathrm{mg} \text { protein }\right)\end{array}$ & $\begin{array}{l}\text { Glucose-6-phosphate } \\
\text { dehydrogenase } \\
\text { (U\#/mg protein })\end{array}$ & $\begin{array}{l}\text { Glucose-6 phosphatase } \\
\text { (Unit@/min/ } \\
\text { mg protein) }\end{array}$ & $\begin{array}{l}\text { Fructose 1,6-bis } \\
\text { phosphatase }(\text { Unit } \$ \text { /h/ } \\
\text { mg protein })\end{array}$ \\
\hline Control & $0.30 \pm 0.03^{\mathrm{a}}$ & $4.62 \pm 0.36^{\mathrm{a}}$ & $5.76 \pm 0.41^{\mathrm{a}}$ & $13.41 \pm 0.99^{\mathrm{a}}$ \\
\hline Diabetic control & $0.10 \pm 0.01^{\mathrm{b}}$ & $2.57 \pm 0.19^{\mathrm{b}}$ & $7.72 \pm 0.61^{\mathrm{b}}$ & $26.47 \pm 2.05^{\mathrm{b}}$ \\
\hline $\mathrm{D}+$ I.p $(300 \mathrm{mg} / \mathrm{kg} \mathrm{bw})$ & $0.25 \pm 0.03^{\mathrm{c}}$ & $3.79 \pm 0.29^{\mathrm{c}}$ & $6.15 \pm 0.47^{\mathrm{c}}$ & $16.44 \pm 1.26^{\mathrm{c}}$ \\
\hline $\mathrm{D}+\mathrm{GC}(6 \mathrm{mg} / \mathrm{kg} \mathrm{bw})$ & $0.28 \pm 0.03^{\mathrm{ac}}$ & $4.18 \pm 0.42^{\mathrm{ac}}$ & $5.47 \pm 0.42^{\mathrm{ac}}$ & $13.76 \pm 1.01^{\mathrm{a}}$ \\
\hline
\end{tabular}

All the data are expressed as the mean \pm S.D. for 6 rats. The results with different superscripts (a,b,c..) in each experimental groups are significantly different at $\mathrm{p}<0.05$.

(D: Diabetic; I.p: I. pes-caprae leaf ethanolic extract; GC: Glibenclamide)

\subsection{Effect of Ipomoea pes-caprae on lipid peroxidation}

TBARS and LOOH levels were significantly $(p<0.05)$ elevated in the organs (pancreas, liver and kidney) of diabetic control rats when compared to control rats, whereas diabetic rats treated with I. pes-caprae leaf ethanol extract and glibenclamide significantly inhibited the increased level of TBARS and $\mathrm{LOOH}$ as compared with diabetic control rats (Table 2). 
Table 2: The levels of lipid peroxidation markers (TBARS and LOOH) in different tissues of experimental and control rats

\begin{tabular}{|c|c|c|c|c|}
\hline Groups & Control & Diabetic control & $\begin{array}{c}\text { D + I.p } \\
(300 \mathrm{mg})\end{array}$ & $\begin{array}{l}D+G C \\
(6 \mathrm{mg})\end{array}$ \\
\hline \multicolumn{5}{|c|}{ TBARS1 } \\
\hline Liver & $0.79 \pm 0.06^{\mathrm{a}}$ & $3.09 \pm 0.20^{\mathrm{b}}$ & $1.77 \pm 0.14 \mathrm{c}$ & $1.47 \pm 0.12^{\mathrm{c}}$ \\
\hline Kidney & $1.32 \pm 0.11^{\mathrm{a}}$ & $3.32 \pm 0.23^{b}$ & $2.19 \pm 0.15^{c}$ & $1.63 \pm 0.13^{\mathrm{a}}$ \\
\hline Pancreas & $0.30 \pm 0.03^{a}$ & $0.49 \pm 0.03^{b}$ & $0.38 \pm 0.03^{c}$ & $0.37 \pm 0.03^{a}$ \\
\hline \multicolumn{5}{|c|}{$\mathrm{LOOH}^{2}$} \\
\hline Liver & $72.10 \pm 5.54^{a}$ & $124.62 \pm 9.66^{b}$ & $84.78 \pm 6.61^{c}$ & $77.30 \pm 5.72^{\mathrm{ac}}$ \\
\hline Kidney & $66.77 \pm 5.10^{a}$ & $153.17 \pm 11.89 \mathrm{~b}$ & $78.68 \pm 6.01^{c}$ & $75.18 \pm 5.24 \mathrm{ac}$ \\
\hline Pancreas & $16.54 \pm 1.27^{\mathrm{a}}$ & $29.38 \pm 2.25^{b}$ & $18.63 \pm 1.61^{c}$ & $17.27 \pm 1.27 \mathrm{ac}$ \\
\hline
\end{tabular}

1TBARS in tissues were expressed as $\mu$ moles/g tissue

${ }^{2} \mathrm{LOOH}$ in tissues were expressed as $\times 10^{-5} \mathrm{mmoles} / \mathrm{g}$ tissue

All the data are expressed as the mean \pm S.D. for 6 rats. The results with different superscripts (a,b,c..) in each experimental group are significantly different at $p<0.05$.

(D: Diabetic; I.p: I. pes-caprae leaf ethanolic extract; GC: Glibenclamide)

\subsection{Effect of Ipomoea pes-caprae on enzymatic} antioxidant enzymes

Table 3 depicts the enzymatic antioxidant activities in organs (pancreas, liver and kidney) of experimental and control rats. The activity of enzymatic antioxidant enzymes such as SOD, CAT and GPx were significantly declined in diabetes control rats when compared with control rats. $I$. pes-caprae leaf ethanol extract and glibenclamide treated diabetic rats showed significant improvement in the activity of SOD, CAT and GPx as compared to diabetic control rats.

Table 3: The levels of enzymatic antioxidants in different tissues of experimental and control rats

\begin{tabular}{|l|c|c|c|c|}
\hline \multicolumn{1}{|c|}{ Groups } & Control & Diabetic control & $\begin{array}{c}\text { D + BC } \\
\mathbf{( 5 0 ~ m g )}\end{array}$ & $\begin{array}{c}\text { D + GC } \\
\text { (6 mg) }\end{array}$ \\
\hline \multicolumn{5}{|c|}{ SOD $^{\mathbf{1}}$} \\
\hline Liver & $9.34 \pm 0.71^{\mathrm{a}}$ & $4.78 \pm 0.34^{\mathrm{b}}$ & $7.76 \pm 0.62^{\mathrm{c}}$ & $8.39 \pm 0.67^{\mathrm{a}}$ \\
\hline Kidney & $14.31 \pm 1.10^{\mathrm{a}}$ & $6.49 \pm 0.52^{\mathrm{b}}$ & $12.34 \pm 0.93^{\mathrm{c}}$ & $12.64 \pm 1.01^{\mathrm{ac}}$ \\
\hline Pancreas & $3.19 \pm 0.24^{\mathrm{a}}$ & $1.67 \pm 0.12^{\mathrm{b}}$ & $2.73 \pm 0.20^{\mathrm{c}}$ & $2.82 \pm 0.21^{\mathrm{a}}$ \\
\hline \multicolumn{5}{|c|}{$\mathbf{C A T}^{\mathbf{2}}$} \\
\hline Liver & $80.06 \pm 6.17^{\mathrm{a}}$ & $51.67 \pm 4.03^{\mathrm{b}}$ & $67.78 \pm 5.13^{\mathrm{c}}$ & $70.35 \pm 5.29^{\mathrm{ac}}$ \\
\hline Kidney & $40.23 \pm 3.07^{\mathrm{a}}$ & $18.21 \pm 1.38^{\mathrm{b}}$ & $32.58 \pm 2.51^{\mathrm{c}}$ & $35.14 \pm 2.71^{\mathrm{a}}$ \\
\hline Pancreas & $0.74 \pm 0.05^{\mathrm{a}}$ & $0.39 \pm 0.03^{\mathrm{b}}$ & $0.64 \pm 0.05^{\mathrm{c}}$ & $0.72 \pm 0.05^{\mathrm{a}}$ \\
\hline \multicolumn{5}{|c|}{$\mathbf{G P X}^{\mathbf{3}}$} \\
\hline Liver & $11.21 \pm 0.87^{\mathrm{a}}$ & $4.82 \pm 0.37^{\mathrm{b}}$ & $9.20 \pm 0.71^{\mathrm{c}}$ & $10.38 \pm 0.79^{\mathrm{ac}}$ \\
\hline Kidney & $8.38 \pm 0.66^{\mathrm{a}}$ & $4.26 \pm 0.31^{\mathrm{b}}$ & $6.59 \pm 0.53^{\mathrm{c}}$ & $7.64 \pm 0.58^{\mathrm{a}}$ \\
\hline Pancreas & $1.69 \pm 0.12^{\mathrm{a}}$ & $0.97 \pm 0.08^{\mathrm{b}}$ & $1.38 \pm 0.11^{\mathrm{c}}$ & $1.59 \pm 0.12^{\mathrm{ac}}$ \\
\hline
\end{tabular}

${ }^{1}$ SOD for tissues were expressed as $50 \%$ inhibition of nitroblue tetrazolium reduced in $1 \mathrm{minute} / \mathrm{mg}$ protein

${ }^{2} \mathrm{CAT}$ for tissues were expressed as $\mu$ moles of $\mathrm{H}_{2} \mathrm{O}_{2}$ consumed/ minute/mg protein.

${ }^{3} \mathrm{GPx}$ for tissues were expressed as $\mu \mathrm{g}$ of GSH consumed /minute/mg protein

All the data are expressed as the mean \pm S.D. for 6 rats. The results with different superscripts $(a, b, c .$.$) in each experimental$ groups are significantly different at $p<0.05$.

(D: Diabetic; I.p: I. pes-caprae leaf ethanolic extract; GC: Glibenclamide)

\subsection{Effect of Ipomoea pes-caprae on non-enzymatic antioxidants}

Table 4 shows the level of non-enzymatic antioxidants in tissue (pancreas, liver and kidney) of control and experimental rats. The GSH, vitamin $\mathrm{C}$ and $\mathrm{E}$ levels were significantly declined in diabetic control rats when compared to control rats. These abnormal levels of nonenzymatic antioxidants improved considerably to near normal levels in $I$. pes-caprae leaf ethanol extract and glibenclamide treated diabetic rats. 
Table 4: The levels of non-enzymatic antioxidants in different tissues of experimental and control rats

\begin{tabular}{|c|c|c|c|c|}
\hline Groups & Control & Diabetic control & $\begin{array}{c}D+I . p \\
(300 \mathrm{mg} / \mathrm{kg} \mathrm{bw})\end{array}$ & $\begin{array}{c}D+G C \\
(6 \mathrm{mg} / \mathrm{kg} \mathrm{bw})\end{array}$ \\
\hline \multicolumn{5}{|c|}{ GSH1 } \\
\hline Plasma & $30.19 \pm 2.39 \mathrm{a}$ & $15.67 \pm 1.17 \mathrm{~b}$ & $24.18 \pm 1.79 c$ & $25.09 \pm 1.89 \mathrm{c}$ \\
\hline Liver & $13.36 \pm 1.09^{a}$ & $8.07 \pm 0.61^{b}$ & $11.79 \pm 0.89 c$ & $12.88 \pm 0.96^{\mathrm{ac}}$ \\
\hline Kidney & $12.49 \pm 0.96^{\mathrm{a}}$ & $6.61 \pm 0.50^{b}$ & $10.28 \pm 0.80^{c}$ & $11.29 \pm 0.86^{\mathrm{ac}}$ \\
\hline Heart & $10.21 \pm 0.78^{a}$ & $5.25 \pm 0.41^{b}$ & $8.75 \pm 0.68^{c}$ & $9.10 \pm 0.70^{\mathrm{ac}}$ \\
\hline Pancreas & $1.78 \pm 0.13^{\mathrm{a}}$ & $0.90 \pm 0.07 \mathrm{~b}$ & $1.39 \pm 0.11^{c}$ & $1.55 \pm 0.12^{\mathrm{a}}$ \\
\hline \multicolumn{5}{|c|}{ Vitamin $\mathrm{C}^{2}$} \\
\hline Plasma & $2.19 \pm 0.11^{\mathrm{a}}$ & $0.75 \pm 0.09 \mathrm{~b}$ & $1.64 \pm 0.13^{c}$ & $1.89 \pm 0.14^{\mathrm{ac}}$ \\
\hline Liver & $0.89 \pm 0.08^{\mathrm{a}}$ & $0.44 \pm 0.03^{b}$ & $0.72 \pm 0.06^{c}$ & $0.83 \pm 0.08^{a}$ \\
\hline Kidney & $0.79 \pm 0.06^{\mathrm{a}}$ & $0.53 \pm 0.05^{b}$ & $0.69 \pm 0.05^{c}$ & $0.76 \pm 0.06^{\mathrm{ac}}$ \\
\hline Heart & $0.49 \pm 0.03^{\mathrm{a}}$ & $0.23 \pm 0.02^{b}$ & $0.39 \pm 0.03^{c}$ & $0.47 \pm 0.04 \mathrm{ac}$ \\
\hline Pancreas & $2.41 \pm 0.18^{\mathrm{a}}$ & $1.32 \pm 0.10^{\mathrm{b}}$ & $2.09 \pm 0.16^{c}$ & $2.30 \pm 0.18 \mathrm{ac}$ \\
\hline \multicolumn{5}{|c|}{ Vitamin $\mathrm{E}^{2}$} \\
\hline Plasma & $1.89 \pm 0.14^{\mathrm{a}}$ & $3.21 \pm 0.27 \mathrm{~b}$ & $2.32 \pm 0.19 \mathrm{c}$ & $2.17 \pm 0.18^{\mathrm{c}}$ \\
\hline Liver & $5.79 \pm 0.46^{\mathrm{a}}$ & $3.88 \pm 0.29 \mathrm{~b}$ & $4.48 \pm 0.33^{c}$ & $4.99 \pm 0.39 c$ \\
\hline Kidney & $3.59 \pm 0.27 \mathrm{a}$ & $1.30 \pm 0.10^{\mathrm{b}}$ & $2.89 \pm 0.23^{c}$ & $3.02 \pm 0.29 a$ \\
\hline Heart & $3.44 \pm 0.25^{\mathrm{a}}$ & $1.63 \pm 0.13^{b}$ & $2.84 \pm 0.21^{c}$ & $3.05 \pm 0.23^{\mathrm{a}}$ \\
\hline Pancreas & $2.69 \pm 0.21^{\mathrm{a}}$ & $1.37 \pm 0.11^{b}$ & $2.51 \pm 0.19^{c}$ & $2.77 \pm 0.25^{\mathrm{ac}}$ \\
\hline
\end{tabular}

$1 \mathrm{GSH}$ for tissues were expressed as $\mu \mathrm{g} / \mathrm{mg}$ protein

2Vitamin E and vitamin C in plasma and tissues were expressed as $\mu$ mole/mg tissue respectively.

All the data are expressed as the mean \pm S.D. for 6 rats. The results with different superscripts $(a, b, c .$.$) in each experimental$ group are significantly different at $p<0.05$.

(D: Diabetic; I.p: I. pes-caprae leaf ethanolic extract; GC: Glibenclamide)

\subsection{Histopathology of Pancreas}

Figure 2 illustrates the histology of experimental and control rats. The pancreas, the target tissue of diabetic etiology, showed severe damage in the case of STZ treated animals. The sinusoids as well as the islet cells of the control animals displayed normal tissue architecture, whereas, the STZ treated animals showed necrotic cells in the tissue sections. I. pes-caprae extract administered groups showed regeneration of islet cells and the same effect were observed with standard glibenclamide treated group.

Figure 2: Histopathology of pancreas in experimental and control rats

A

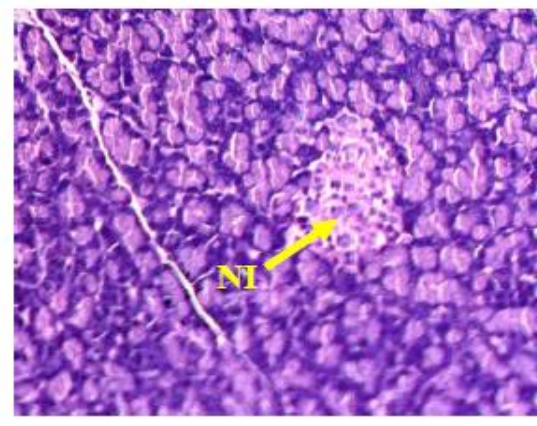

C

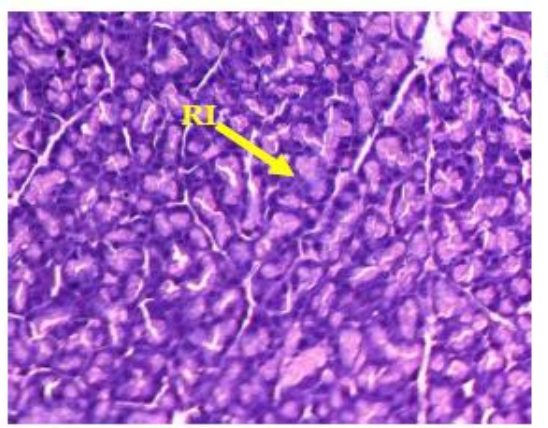

B

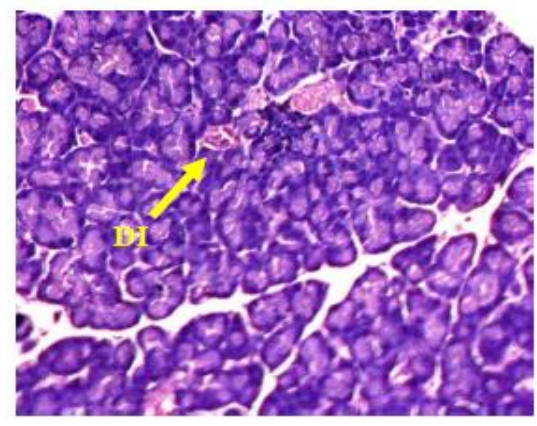

D

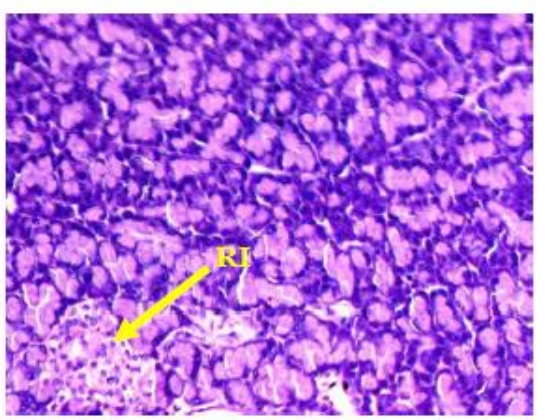

A- Control Pancreas (NI: Normal Islets); B- Diabetic Pancreas (DI: Damaged Islets)

C-Ipomoea pes-caprae extract treated Pancreas ( RI: Recovering Islets)

D- Glibenclamide treated Pancreas (RI: Recovered Islets) 


\subsection{Histopathology of Liver}

The histopathology of liver tissues of control animals revealed ideal hepatocytes whereas, STZ treated animals displayed distorted tissue architecture and damaged liver hepatocytes accompanied with degeneration in the major blood sinusoids were undergoing degeneration, which are the characteristics of STZ induced diabetic animal liver. The I. pes-caprae extract and glibenclamide drug-treated groups showed tissue regeneration with prominent near normal hepatocytes (Figure 3).

Figure 3: Histopathology of liver in experimental and control rats

A

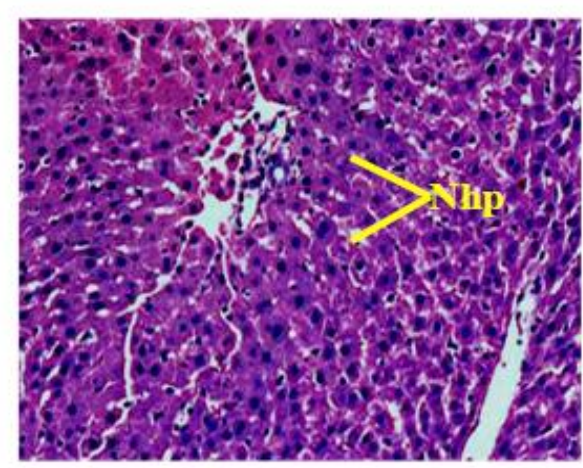

C

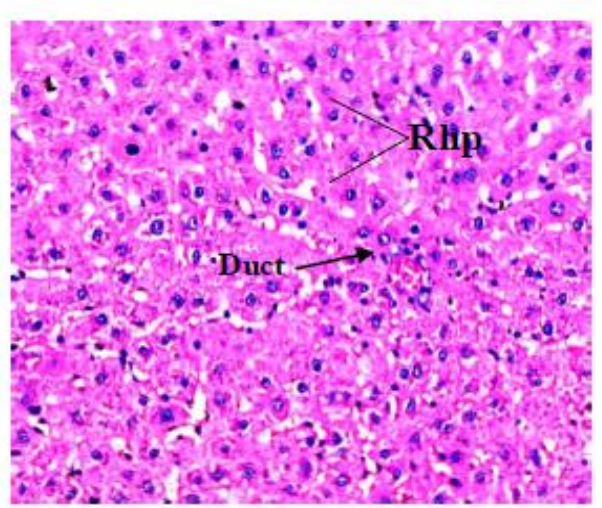

B

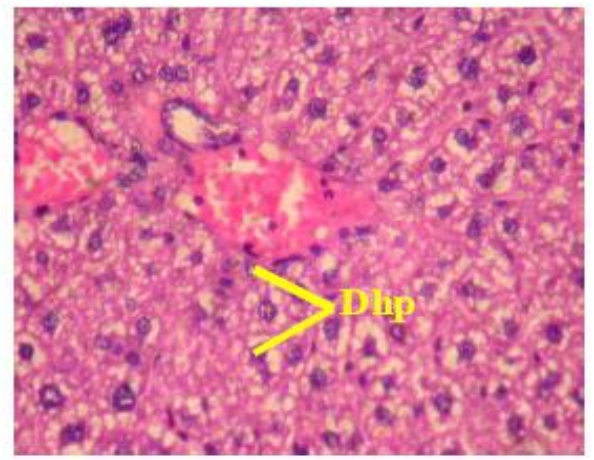

D

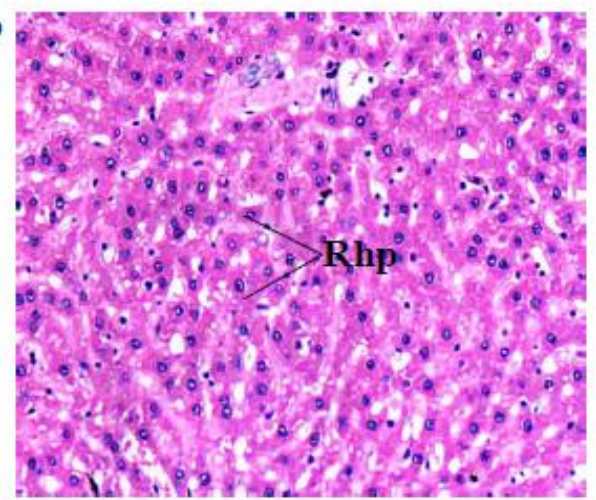

A- Control liver (Nhp: Normal hepatocytes)

B-Diabetic liver (STZ treated) (Dhp: Damaged hepatocytes)

C-Ipomoea pes-caprae extract treated liver (Rhp: Recovered hepatocytes)

D- Glibenclamide treated liver (Standard Drug)

\subsection{Histopathology of Kidney}

The kidney, the ultrafiltration unit of the body, plays a major role in glucose absorption. STZ administration causes severe necrosis accompanied by glomeruli damage in the kidney of diabetic control rat. Ipomoea pes-caprae extract treated diabetic animals displayed considerable tissue recovery and the results were comparable to glibenclamide (standard drug) treated animals (Figure 4). 

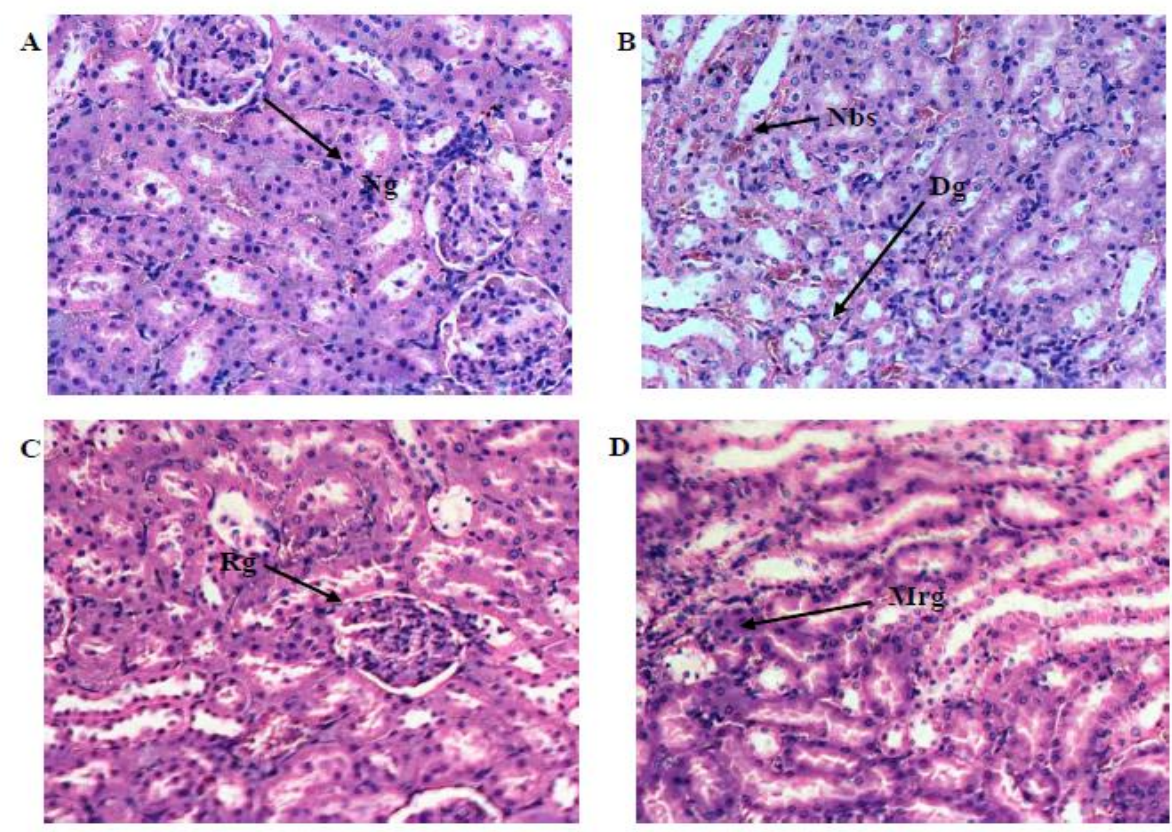

A-Control kidney (Normal treated) (Ng: Normal glomeruli)

B- Diabetic kidney (Nbs: Necrosized sinusoids; Dg: Damaged glomeruli))

C-Ipomoea pes-caprae extract treated kidney (Rg: Regenerative glomeruli)

D- Glibenclamide treated kidney (Mrg: Moderate regenerative glomeruli)

\section{DISCUSSION}

Medicinal plants have created the foundation of the health care system throughout the world since the initial stage of humanity and still plant products is the major source of drug/formulation in the treatment of various diseases [4]. Previously, we have confirmed that Ipomoea pes-caprae leaf ethanolic extract can reduce hyperglycemia and relapse abnormal level of hepatic markers into normal range in STZ induced diabetic rats [10]. Therefore, the goal of this study is to observe whether Ipomoea pes-caprae leaf ethanolic extract ameliorated the abnormal levels of carbohydrate metabolizing enzymes, oxidative status and histology of major organs in STZ induced diabetic rats.

Glycogen is the primary intracellular storage form of glucose and its quantity in various tissues is a direct manifestation of insulin activity as insulin supports intracellular glycogen deposition Pederson et al. [23]. The reduced glycogen store in diabetic rats has been attributed to the loss of glycogen synthase-activating system and/or the increased activity of glycogen phosphorylase [24]. In the present study, there was a decrease in the hepatic glycogen content of diabetic rats that suggests the increased glucose output due to insulin deficiency. Moreover, diabetic animals showed increased glycogen phosphorylase activity when compared with control animals. Treatment with Ipomoea pes-caprae ethanolic leaf extract restored the levels of glycogen, probably by means of decreasing the activity of glycogen phosphorylase.

Glucose homeostasis deals with the balance in the endogenous production as well as the glucose utilization by the target tissues [25]. Insulin, a major player in glucose homeostasis, is responsible for regulating the activities of various enzymes like hexokinase, glucose-6-phosphate dehydrogenase, glucose-6-phosphatase as well as fructose 1,6-bisphosphatase, which are associated with carbohydrate metabolism in the body [26]. Glucokinase, a key enzyme involved in glycolysis, catalyzes the conversion of glucose to glucose 6-phosphate (in the liver) and plays a very important role in maintaining blood glucose homeostasis [27]. Being an insulin-dependent enzyme, the hepatic glucokinase activity of diabetic rats is almost entirely inhibited or inactivated due to the lack of insulin that ultimately leads to hyperglycaemia [27]. The diabetic control rats showed a significant reduction in the level of hexokinase when compared to control rats. Oral administration of I. pescaprae ethanol leaf extract to STZ-induced diabetic rats resulted in a significant reversal in the activity of glucokinase, thereby increasing the oxidation of glucose. Several previous studies reported that glucokinase is the potential target for new treatment strategies for the management of type 2 diabetes [24, 26].

Glucose-6-phosphate dehydrogenase is the first and also the rate-limiting enzyme of the pentose phosphate pathway, which is involved in the formation of ribose-5-phosphate and also NADPH [29]. Thus, its low activity leads to a decrease in NADPH and makes cells very sensitive to oxidative damage. In the diabetic condition, the decrease in the activity of glucose-6-phosphate dehydrogenase hinders the pentose phosphate pathway [32]. In the present study, treatment with I. pes-caprae ethanolic leaf extract improved the activity of glucose-6-phosphate dehydrogenase in STZinduced diabetic rats that may be due to the improved level of insulin secretion.

Glucose-6-phosphatase and fructose-1, 6-bisphosphatase are the regulatory enzymes in the gluconeogenic pathway. The actions of these two enzymes may be attributed to the increased glucose production during the diabetic condition by the liver [30]. The activities of hepatic glucose-6phosphatase and fructose-1,6-bisphosphatase increase 
significantly in diabetic rats [31]. The oral treatment of $I$. pes-caprae ethanolic leaf extract significantly declined the activities of glucose-6-phosphatase and fructose-1, 6bisphosphatase in STZ-induced diabetic rats, which may lead to the suppression of glucose production from noncarbohydrate substances.

In the present study, the concentration of tissue TBARS was significantly increased in the liver and kidney and pancreas of diabetic rats as reported earlier in clinical and experimental diabetes [32]. The increased concentration of lipid peroxidative markers suggests an increased level of oxygen free radicals, either by increased production or decreased destruction [33]. The administration of Ipomoea pes-caprae leaf extract reduced TBARS in the tissues of diabetic rats suggesting that the extract possesses potent antioxidant properties. The strong antioxidant property displayed by the extract is in accordance with earlier findings [34].

The level of lipid peroxidation in cells is controlled by various cellular defense mechanisms consisting of enzymatic scavenger systems [35]. SOD, CAT and GPx constitute a mutually supportive defense system against ROS. Functions of these antioxidant enzymes are interconnected and a decrease of their activities results in the accumulation of lipid peroxides and increase oxidative stress in diabetic rats [36]. The level of enzymatic antioxidants (SOD, CAT and GPx) was significantly restored to near normal after treatment with Ipomoea pes-caprae leaf extract in diabetic rats. This indicates the modulatory activity of Ipomoea pescaprae leaf extract over SOD, CAT and GPx enzyme production, which help restore the oxidant status in diabetic rats.

Glutathione is a tripeptide, intracellular non-enzymic antioxidant that protects the cellular system from adverse effects of lipid peroxidation. It directly scavenges free radicals and acts as a co-substrate for peroxide detoxification by glutathione peroxidases [37]. Increased oxidative stress due to a significant increase in aldehydic products of lipid peroxidation could probably decrease GSH availability in the cell [38]. It has been previously reported that the treatment with Ipomoea pes-caprae leaf extract result in the elevation of the GSH levels, which protects the cell membrane from the oxidative damage by regulating the redox status [39]. Vitamin C plays a vital role in the antioxidant system that protects all lipids from undergoing oxidation. Moreover, it helps in diminishing count of apoptotic cells [40] and helps to regenerate vitamin E from its oxidized state [41]. Vitamin $E$ is a non-enzymatic antioxidant that helps reduce chain reactions associated with lipid peroxidation [42]. Vitamin $\mathrm{E}$ is also reported to be very effective in the glycemic control and also helps in lowering the level of HbA1c, the glycated haemoglobin, used as a marker to measure average blood glucose [43]. In our studies, diabetic control rats showed significant decline in the levels of GSH, vitamin C and vitamin E, while Ipomoea pes-caprae leaf extract administration in STZ-induced experimental DM rats expressed near normal levels of GSH, vitamin $\mathrm{C}$ and $\mathrm{E}$. Thus, the obtained results display the potential of Ipomoea pes-caprae ethanolic leaf extract to restore the non-enzymatic and enzymatic antioxidant reserves.

The most abundant cell type found in the endocrine region of the pancreas is the $\beta$-cell. The number of $\beta$-cell present in the pancreas is the most vital factor determinant of the islet area [32]. The pancreas of the diabetic rats displayed ruptured islets as well as a decrease in the number of $\beta$-cell count. Thus, the islet area was reduced considerably in the diabetic rats, which was found restored in Ipomoea pescaprae extract and glibenclamide treated diabetic rats. The restoration of damages in the pancreas may be due to the improved control over the activity of free radical by the Ipomoea pes-caprae extract.

The liver is the vital organ that is involved in the blood glucose homeostasis in the body. Both the liver and kidney exhibit various morphological as well as functional modifications during diabetes [31]. The diabetic control liver showed damaged hepatocytes with periportal necrosis near the portal region with dilated as well as congestion in the portal vessels and inflammatory cell infiltration. Moreover, the diabetic kidney displayed damaged tubules, lessons and fatty infiltration along with thickened glomeruli matrix and basement membranes of proximal as well as distal convoluted tubules. The above observations in diabetic control liver and kidney tissues were in line with the previous reportings by Ojiako et al. [44]. Hyperglycemias as well as glycation of proteins are the main cause of the damages that occurr in diabetic rats [44]. The restoration of damages in the liver and kidney of diabetic rats treated with Ipomoea pes-caprae extract and glibenclamide may be due to improved glycemic control and thereby control over free radical production and glycation of proteins.

The effectiveness of the Ipomoea pes-caprae leaf extract in ameliorating the glucose and oxidant status in the diabetic rats may be contributed to the presence of secondary metabolites such phenols, sterols, alkaloids, flavonoids, etc., in leaf of Ipomoea pes-caprae $[45,46]$.

\section{CONCLUSION}

The treatment of Ipomoea pes-caprae $(300 \mathrm{mg} / \mathrm{kg} \mathrm{b.w})$ notably inhibits the oxidative stress, while carbohydrate metabolizing enzyme levels were also improved in the liver of diabetic rats. These findings clearly displayed recovered carbohydrate metabolizing enzymes that prevent hepatic glucose production and also enhanced utilization of glucose by cells. Further study is required to find out the major secondary metabolites that are responsible for regulation of hyperglycemia in diabetic condition.

\section{REFERENCES}

1. Farajpour R, Sadigh-Eteghad S, Ahmadian N, Farzipour M, Mahmoudi J, Majdi A. Chronic Administration of Rosa canina Hydro-Alcoholic Extract Attenuates Depressive-Like Behavior and Recognition Memory Impairment in Diabetic Mice: A Possible Role of Oxidative Stress. Med Princ Pract. 2017;26(3):245-50.

2. International Diabetes Federation. IDF Diabetes Atlas, 8th edn. Brussels, Belgium: International Diabetes Federation 2017. http://www.diabetesatlas.org

3. Kim HJ, Han SJ, Kim DJ, Jang HC, Lim S, Choi SH, et al. Effects of valsartan and amlodipine on oxidative stress in type 2 diabetic patients with hypertension: a randomized, multicenter study. Korean J Intern Med (Korean Assoc Intern Med)., 2017; 32(3):497-504.

4. Anup KM, Smriti T, Zabeer A, Ram KS. Antidiabetic and antihhyperlipidemic effect of Euphorbia hirta in streptozotocin induced diabetic rats. Scholars Research Library, 2012; 4 (2): 703-707.

5. De Souza MM, Madeira AO, Berti C, Krogh R, Yunes RA, CechinelFilho V. Antinociceptive properties of the methanolic extract obtained from Ipomoea pes-caprae (L.) R. Br. J Ethnopharmacol., 2000; 69 (1): 85-90.

6. Sen DT, Tan DV, La HT. Biological activity of methanolic extract derived from Ipomea pes-caprae (L.) collected in Xuan Thuy national park. J Sci Hnue. 2013; 58(9):139-145.

7. Venkataraman ND, Atlee WC, Prabhu TP, Kannan R. Antiinflammatory potential of ethanolic extracts from aerial parts of Ipomoea pes-caprae (L.) R.Br using cotton pellet induced granuloma model. J Appl Pharmaceut Sci. 2013; 3(7):61-63. 
8. Robert P, Retna A. Trihydroxyisoflavone isolated from Ipomea pes-caprae roots by normal phase column chromatography. Bull Environ Pharmacol Life Sci. 2016; 5(5):27-33.

9. Bragadeeswaran S, Prabhu K, Rani SS, Priyadharsini S, Vembu N. Biomedical application of beach morning glory Ipomoea pescaprae. Int J Trop Med. 2010; 5:81-5

10. Suhasini S, Elanchezhiyan C, Babby A. Hepatoprotective effect of Ipomoea pes-caprae leaves extract in Streptozotocin induced diabetic rats. International Journal of Pharmacy and Pharmaceutical Science Research 2014; 4(2): 27-30.

11. Shirwaikar A, Rajendran K, Punitha IS. Antidiabetic activity of alcoholic stem extract of Coscinium fenestratum in streptozotocin-nicotinamide induced type 2 diabetic rats. Journal of Ethnopharmacology, 2005; 97: 369-374.

12. Brandstrup N, Kirk JE, Bruni C. The hexokinase and phosphoglucoisomerase activities of aortic and pulmonary artery tissue in individuals of various ages.Journal of Gerontology, 1957; 12, 166-171.

13. Ellis HA, Kirkman HN. A colorimeteric method for assay of erythrocyte glucose-6-phosphate dehydrogenase. Proceedings of the Society for Experimental Biology and Medicine, 1961; 106: 607-609.

14. Koide H, Oda T. Pathological occurrence of glucose 6phosphatase in serum in liver diseases. Clinica Chimica Acta, 1957; 4: 554-61.

15. Gancedo JM, Gancedo C. Fructose 1, 6-bisphophatase, phosphofructokinase and glucose 6-phosphate dehydrogenase from fermenting yeast. Archives of Microbiology, 1971; 76: 132138.

16. Ohkawa H, Ohishi N, Yagi K. Assay for lipid peroxidation in animal tissues by thiobarbituric acid reaction. Annals of Clinical Biochemistry, 1979; 95: 351-358.

17. Kakkar P, Das B, Viswanathan P. A modified method for assay of superoxide dismutase. Indian journal of biochemistry \& biophysics, 1984; 21, 131-132.

18. Sinha AK. Colorimetric assay of catalase. Analytical Biochemistry, 1972; 47: 389-394.

19. Rotruck JT, Pope AL, Ganther HE, Swanson AB, Hafeman DG, Hoekstra WG. Selenium: biochemical role as a component of glutathione peroxidase. Science, 1973; 179: 588-90.

20. Ellman, G. Tissue sulphydryl groups. Archives of Biochemistry and Biophysics, 1959; 32: 70-77.

21. Omaye ST, Tumbul TD. Saubelich HC. Selected method for the determination of ascorbic acid in animal cells, tissues and fluids. MC Cormic B.D., Wright DL, (Eds), Methods Enzymology, 1979; 62: 3-11.

22. Baker AF, Frank G. Estimation of Vitamin $E$ in tissues. In: Bollinger G, ed, Dunnschicht.Chromaeographic in Laboratorium Handbuch. Springer Verlag, Berlin, 1951; 41-52.

23. Pederson BA, Schroeder JM, Parker GE, et al.. Glucose metabolism in mice lacking muscle glycogen synthase. Diabetes, 2005; 54: 3466-73.

24. Chandirasegaran G, Elanchezhiyan C, Ghosh K, Effects of Berberine chloride on the liver of streptozotocin-induced diabetes in albino Wistar rats. Biomedicine and pharmacotherapy, 2018; 99: 227-236.

25. Wilding JP. The role of the kidneys in glucose homeostasis in type 2 diabetes: clinical implications and therapeutic significance through sodium glucose co-transporter 2 inhibitors. Met Clin Exp., 2014; 63:1228-1237.

26. Prasath GS, Subramanian SP. Antihyperlipidemic effect of fisetin, a bioflavonoid of strawberries, studied in streptozotocininduced diabetic rats. J Biochem Mol Toxicol., 2014; 28:442449.

27. Matschinsky FM. Assessing the potential of glucokinase activators in diabetes therapy. Nat Rev Drug Discov. 2009; 8:399-416.

28. Selvaraja W, William Ndyeabura A. Antidiabetic activity of crude stem extracts of coscinium fenestratum on streptozotocininduced type-2 diabetic rats. A J Pharma Clin Res. 2011; 4:4751.
29. Xu Y, Osborne BW, Stanton RC. Diabetes causes inhibition of glucose-6-phosphate dehydrogenase via activation of PKA which contributes to oxidative stress in rat kidney cortex. The American Journal of Physiology - Renal Physiology, 2005; 289: 1040-1047.

30. Pari L, Saravanan R. Succinic acid monoetheyl ester and metformin regulates carbohydrate metabolic enzymes and improves glycemic control in streptozotocin-nicotinamide induced type 2 diabetic rats. Iranian Journal of Pharmacology \& Therapeutics, 2005; 4: 132-137.

31. Lekshmi RK, Sreekutty MS, Mini S. The regulatory effects of Cissus quadrangularis on some enzymes involved in carbohydrate metabolism in streptozotocin-induced diabetic rats. Pharmaceutical Biology, 2015; 53, 1194-1200.

32. Chandirasegaran G, Elanchezhiyan C, Ghosh K, Sethupathy S, Berberine chloride ameliorates oxidative stress, inflammation and apoptosis in the pancreas of Streptozotocin induced diabetic rats. Biomedicine and pharmacotherapy 2017 (95): 175185.

33. Kakkar, P., Das, B and Viswanathan, P.N., 1984. A modified spectrophotometric assay of superoxide dismutase. Ind J Biochem Biophys, 21(2): 130-132.

34. Ahmed RS and Sharma SB. Biochemical studies on combined effects of garlic (Allium sativum Linn) and ginger (Zingiber officinale Rosc) in albino rats. Indian J Exp Biol. 1997; 35(8): 841-3.

35. Halliwell B, Gutteridge JMC. 1999. Free radicals in biology and medicine. 3rd ed. UK, Oxford Science Publications, pp: 192.

36. Sen CK, Hanninen O. 1994. Physiological Antioxidants. In: Sen, C.K., Packer, L., Hanninen, O. (Eds), Exercise and oxygen toxicity. Elsevier, New York ., PP. 89-126

37. Winterbourn C.C. 1995. Concerted antioxidant activity of glutathione and superoxide dismutase. In: Packer L, Fuchs J, eds. Biothiols in health and disease. New York: Marcel Dekker Inc, p. 117-34.

38. Mohammed AH. Antidiabetic and antioxidant activity of Jasonia montana extract in streptozotocin-induced diabetic rats. Saudi Pharmaceutical Journal, 2008; 16: 3-4.

39. Inove M, Saito Y. Hirato, E, Morino, Y., Nagase S. Regulation of redox status of plasma proteins by mechanism and transport of glutathione and related compounds. Journal of Protein Chemistry, 1987; 36: 169-173.

40. Sadi G, Yllmaz O, Güray, T. (2008). Effect of vitamin C and lipoic acid on streptozotocin-induced diabetes gene expression: mRNA and protein expressions of $\mathrm{Cu}-\mathrm{Zn}$ SOD and catalase. Molecular and Cellular Biochemistry, 2008; 309: 109-116.

41. Chung-Yen Chen PE, Milbury K, Lapsley JB. Blumberg, Flavonoids from Almond Skins Are Bioavailable and Act Synergistically with Vitamins C and E to Enhance Hamster and Human LDL Resistance to Oxidation. Journal of Nutrition, 2005; 135: 1366-1373.

42. Punithavathi VR, Anuthama R, Prince PS. Combined treatment with naringin and vitamin $\mathrm{C}$ ameliorates streptozotocin-induced diabetes in male wistar rats. The Journal of Applied Toxicology, 2008; 28: 806-13.

43. Ihara A, Matsumoto K, Kawamoto T., Shouno S., Kawamoto J, Katayama A, Yoshitatsu M., Izutani H. Relationship between hemostatic markers and platelet indices in patients with aortic aneurysm. Pathophysiology of haemostasis and thrombosis, 2006; 35: 451-456.

44. Ojiako OA, Chikezie PC, Ogbuji AC. Histopathological studies of renal and hepatic tissues of hyperglycemic rats administered with traditional herbal formulations. Int J Green Pharm 2015; 9:184-91

45. Ratnasooriya WD, Pathirana RN, Dissanayake AS, Samanmali RS Methanolic leaf extract of Ipomoea pes-caprae possesses in vitro sun screen activity. Imperial Journal of Interdisciplinary Research, 2017; 3 (2).

46. Nilam R, Jyoti $P$ and Sumitra C. Pharmacognostic and phytochemical studies of Ipomoea pes-caprae, an halophyte from Gujarat. Journal of Pharmacognosy and Phytochemistry 2018; 7(1): 11-18. 